\title{
Does household use of biomass fuel cause lung cancer? A systematic review and evaluation of the evidence for the GBD 2010 study
}

\author{
Nigel Bruce, ${ }^{1}$ Mukesh Dherani, ${ }^{1}$ Rui Liu, ${ }^{2}$ H Dean Hosgood III, ${ }^{3,4}$ Amir Sapkota, ${ }^{5}$ \\ Kirk R Smith, ${ }^{2}$ Kurt Straif, ${ }^{6}$ Qing Lan, ${ }^{3}$ Daniel Pope ${ }^{1}$
}

- Additional material is published online only. To view please visit the journal online (http://dx.doi.org/10.1136/ thoraxjnl-2014-206625).

For numbered affiliations see end of article.

\section{Correspondence to}

Dr Nigel G Bruce, Department of Public Health and Policy, University of Liverpool, Whelan Building, Quadrangle, Liverpool L69 3GB, UK; ngb@liv.ac.uk

Received 27 November 2014 Revised 16 February 2015 Accepted 17 February 2015 Published Online First 10 March 2015
CrossMark

To cite: Bruce $\mathrm{N}$

Dherani M, Liu R, et al.

Thorax 2015;70:433-441.
ABSTRACT

Background Around 2.4 billion people use traditional biomass fuels for household cooking or heating. In 2006, the International Agency for Research on Cancer (IARC) concluded emissions from household coal combustion are a Group 1 carcinogen, while those from biomass were categorised as $2 \mathrm{~A}$ due to epidemiologic limitations. This review updates the epidemiologic evidence and provides risk estimates for the 2010 Global Burden of Disease study.

Methods Searches were conducted of 10 databases to July 2012 for studies of clinically diagnosed or pathologically confirmed lung cancer associated with household biomass use for cooking and/or heating.

Findings Fourteen eligible studies of biomass cooking or heating were identified: 13 had independent estimates (12 cooking only), all were case-control designs and provided 8221 cases and 11342 controls. The ORs for lung cancer risk with biomass for cooking and/or heating were OR 1.17 (95\% Cl 1.01 to 1.37) overall, and 1.15 (95\% Cl 0.97 to 1.37 ) for cooking only. Publication bias was not detected, but more than half the studies did not explicitly describe a clean reference category. Sensitivity analyses restricted to studies with adequate adjustment and a clean reference category found ORs of 1.21 (95\% Cl 1.05 to 1.39) for men (two reports, compiling five studies) and $1.95(95 \% \mathrm{Cl} 1.16$ to 3.27) for women (five reports, compiling eight studies). Exposure-response evidence was seen for men, and higher risk for women in developing compared with developed countries, consistent with higher exposures in the former.

Conclusions There is now stronger evidence for biomass fuel use causing lung cancer, but future studies need better exposure assessment to strengthen exposureresponse evidence.

\section{INTRODUCTION}

Around 2.8 billion people globally still cook using solid fuels in open fires and simple stoves, ${ }^{1}$ a majority (2.4 billion, $86 \%)$ of whom use biomass fuels, with the remainder using coal. These fuels are typically burned in open fires and traditional, poorly ventilated stoves, leading to high levels of household air pollution (HAP) exposure. ${ }^{2}$

In 2006, the International Agency for Research on Cancer (IARC) reviewed the evidence on the carcinogenicity of household solid fuel combustion, ${ }^{3}$ concluding that indoor emissions from coal combustion are carcinogenic to humans (IARC

\section{Key messages}

What is the key question?

- Does exposure to smoke from biomass fuel use in the home cause lung cancer, and if so, what is the risk?

\section{What is the bottom line?}

- The available evidence strongly supports a causal relationship, almost doubling the risk in women, somewhat less so for men, reflecting their generally lower exposures.

\section{Why read on?}

- Around 2.4 billion people worldwide rely on biomass fuels in the home for cooking and heating, so these findings have important implications for public health.

Group 1). For household biomass combustion emissions, however, the IARC Working Group concluded that there was limited evidence for risk of lung cancer from epidemiologic studies, although evidence for the carcinogenicity of wood-smoke extracts in experimental animals was sufficient. ${ }^{3}$ In addition, they noted the presence of polycyclic aromatic hydrocarbons and other carcinogenic compounds in wood smoke; evidence of mutagenicity of wood smoke; and multiple studies showing cytogenetic damage in humans exposed to wood smoke. Four studies from Taiwan, ${ }^{4}$ Europe, ${ }^{5}$ Japan $^{6}$ and $\mathrm{Mexico}^{7}$ did suggest that smoke from wood combustion is associated with an increased lung cancer risk, however the results on exposure, duration and intensity were difficult to interpret. It was concluded that indoor emissions from household combustion of biomass are probably carcinogenic to humans (Group 2A).

In developing the comparative risk assessment for the 2010 Global Burden of Disease (GBD) study, ${ }^{8}$ a new systematic review was conducted, the subject of this report. This had the following objectives: (1) to update the human epidemiological evidence on lung cancer risk with household use of biomass fuel; (2) to derive risk estimates, including for cooking (the exposure risk used for the GBD-2010 study) and separately for men and women; and (3) to evaluate the strength of evidence for causal inference. 


\section{METHODS}

\section{Systematic review}

We carried out a systematic review and meta-analysis, following PRISMA reporting guidelines ${ }^{9}$ (protocol available on request). Inclusion criteria were human studies that reported household biomass fuel use for cooking and/or heating; differentiated between risk of lung cancer associated with biomass fuels and coal; and provided an effect estimate or sufficient data to calculate one with a 95\% CI, together with information on adjustment procedures. We defined biomass fuel as including wood, straw, grass, crop waste or residue, animal dung and charcoal. We defined lung cancer as primary cancer of any histological type emanating from the lung, trachea or bronchus. All epidemiologic study designs were eligible, and methodological limitations were explored through sensitivity analysis.

We searched 10 databases (seven English, two Spanish and one Chinese language), box 1, covering articles published between 1966 and July 2012 and search terms are listed in table 1.

We screened the selected titles and abstracts to identify potentially relevant articles, with two authors independently reviewing titles, abstracts and then full-text articles to reject studies not meeting inclusion criteria, and reviewing reference lists (figure 1). We assessed study quality using Liverpool Quality Assessment Tools (developed to provide quantitative and narrative summaries of quality for the main epidemiologic study designs) (Pope D et al, personal communication, 2014). For case-control studies, this covered four key areas: case-control selection, outcome definition, exposure assessment and adjustment for confounding, with each paper being graded as strong, moderate or weak in these four areas. Two reviewers carried out data extraction and quality assessment independently, with disagreements resolved with a third reviewer. When necessary, we contacted study authors to clarify methodological issues.

\section{Meta-analysis}

We carried out meta-analysis using RevMan V.5 to calculate pooled ORs, ${ }^{10}$ contacting authors of two studies for sex-specific effect estimates. ${ }^{5}{ }^{11}$ To assess heterogeneity, we used Cochrane's $\mathrm{Q}$ and $\mathrm{I}^{2}$ statistics, and employed a conservative approach to using fixed or random effects meta-analysis (for an $\mathrm{I}^{2}$ value of more than $20 \%$, random effects values were presented if the results were different between the two approaches). We used the generic inverse variance-weighted method for fixed effect meta-analysis, and the method of Der Simonian and Laird for random effects meta-analysis. ${ }^{12}$ To test for publication bias, we

\section{Box 1 Databases searched}

- MEDLINE

- EMBASE

- Cochrane Controlled Trials Register (CCTR)

- Cumulative Index to Nursing and Allied Health Literature (CINAHL)

- Global Health

- Database of Abstracts of Reviews of Effects (DARE)

- African Index Medicus (AIM)

- Scientific Electronic Library Online (SciELO)

- Latin American and Caribbean Health Sciences Information System (LILACS)

- China National Knowledge Infrastructure (CNKI) visually inspected funnel plots, and carried out Egger's and Begg's tests for asymmetry using Stata V.10.0. ${ }^{13}$

\section{RESULTS}

The searches returned 19833 results (figure 1). Filtering of titles and abstracts led to 81 potentially relevant journal articles. Full review identified 21 manuscripts with information on biomass use; seven, however, combined biomass and other solid fuels into one category such as 'traditional' or 'solid fuels' and were excluded (see online supplementary file).

Of the remaining 14 studies, 13 provided independent estimates (one study-Lissowska et $a l^{5}$-was included in the pooled analysis of Hosgood et $a^{14}$ ). All 13 studies were case-control designs, four providing independent estimates for men, 5 11 14-16 and 12 for women; ${ }^{4-7} 11{ }^{14-21}$ one other study provided an estimate for heating or cooking for men and women combined (table 2). ${ }^{22}$

Twelve studies provided separate estimates for cooking with biomass fuel. ${ }^{4-7} 11 \quad 15-21$ The majority of the studies (10) were conducted in Asia (table 2), one in Mexico, and one other multicentre study combining biomass data from Europe, USA and Canada. The study by Lissowska $e t a l^{5}$ was included in the analysis of cooking only and of exposure-response relationships, following reanalysis by one of the coauthors. Table 2 provides details of study location and methods, including the adequacy of adjustment that was assessed as strong in five, moderate in seven and weak in two. In total, the 13 independent studies included data from 8221 cases and 11342 controls.

Table 1 Search terms for systematic review of household biomass use and lung cancer

\begin{tabular}{|c|c|c|}
\hline Anatomical site & Cancer & Exposure \\
\hline $\begin{array}{l}\text { 1. 'lung' } \\
\text { 2. 'bronchus' } \\
\text { 3. 'bronchial' } \\
\text { 4. 'bronchogenic' } \\
\text { 5. 'pulmonary' } \\
\text { 6. 'lower respiratory } \\
\text { tract' } \\
\text { 7. 'trachea' } \\
\text { 8. '1 OR } 2 \text { OR } 3 \text { OR } \\
4 \text { OR } 5 \text { OR } 6 \text { OR } \\
\text { 7' }\end{array}$ & $\begin{array}{l}\text { 9. 'cancer' } \\
\text { 10. 'cancers' } \\
\text { 11. 'carcinoma' } \\
\text { 12. 'carcinomata' } \\
\text { 13. 'neoplasm' } \\
\text { 14. 'neoplasms' } \\
\text { 15. 'tumor' } \\
\text { 16. 'tumors' } \\
\text { 17. 'tumours' } \\
\text { 18. 'tumour' } \\
\text { 19. 'adenocarcinoma' } \\
\text { 20. 'adenocarcinomata' } \\
\text { 21. '*small-cell' } \\
\text { 22. '9 OR } 10 \text { OR } 11 \text { OR } 12 \text { OR } \\
\text { 13 OR } 14 \text { OR } 15 \text { OR } 16 \text { OR } \\
\text { 17 OR } 18 \text { OR } 19 \text { OR } 20 \text { OR } \\
\text { 21' }\end{array}$ & $\begin{array}{l}\text { 23. 'IAP' } \\
\text { 24. 'Indoor air' } \\
\text { 25. 'pollution' } \\
\text { 26. 'pollutant' } \\
\text { 27. 'fuel' } \\
\text { 28. 'fuels' } \\
\text { 29. 'dung' } \\
\text { 30. 'agricultural waste' } \\
\text { 31. 'crop waste' } \\
\text { 32. 'crop residue' } \\
\text { 33. 'biomass' } \\
\text { 34. 'wood' } \\
\text { 35. 'stove' } \\
\text { 36. 'stoves' } \\
\text { 37. 'chula' } \\
\text { 38. 'chulla' } \\
\text { 39. 'oven' } \\
\text { 40. 'ovens' } \\
\text { 41. 'smoke' } \\
\text { 42. 'smoky' } \\
\text { 43. 'heat*' } \\
\text { 44. cook" } \\
\text { 45. light* } \\
\text { 46. burn* } \\
\text { 47. '23 OR } 24 O R 25 O R \\
\text { 26 OR } 27 O R 28 O R \\
29 O R 30 O R 31 O R \\
32 O R 33 O R 34 O R \\
35 O R 36 O R 37 O R \\
38 O R 39 O R 40 O R \\
41 O R 42 O R 43 O R \\
44 O R 45 O R 46 '\end{array}$ \\
\hline $\begin{array}{l}\text { Combined terms } \\
\text { '8 AND } 22 \text { AND 47' }\end{array}$ & & \\
\hline
\end{tabular}



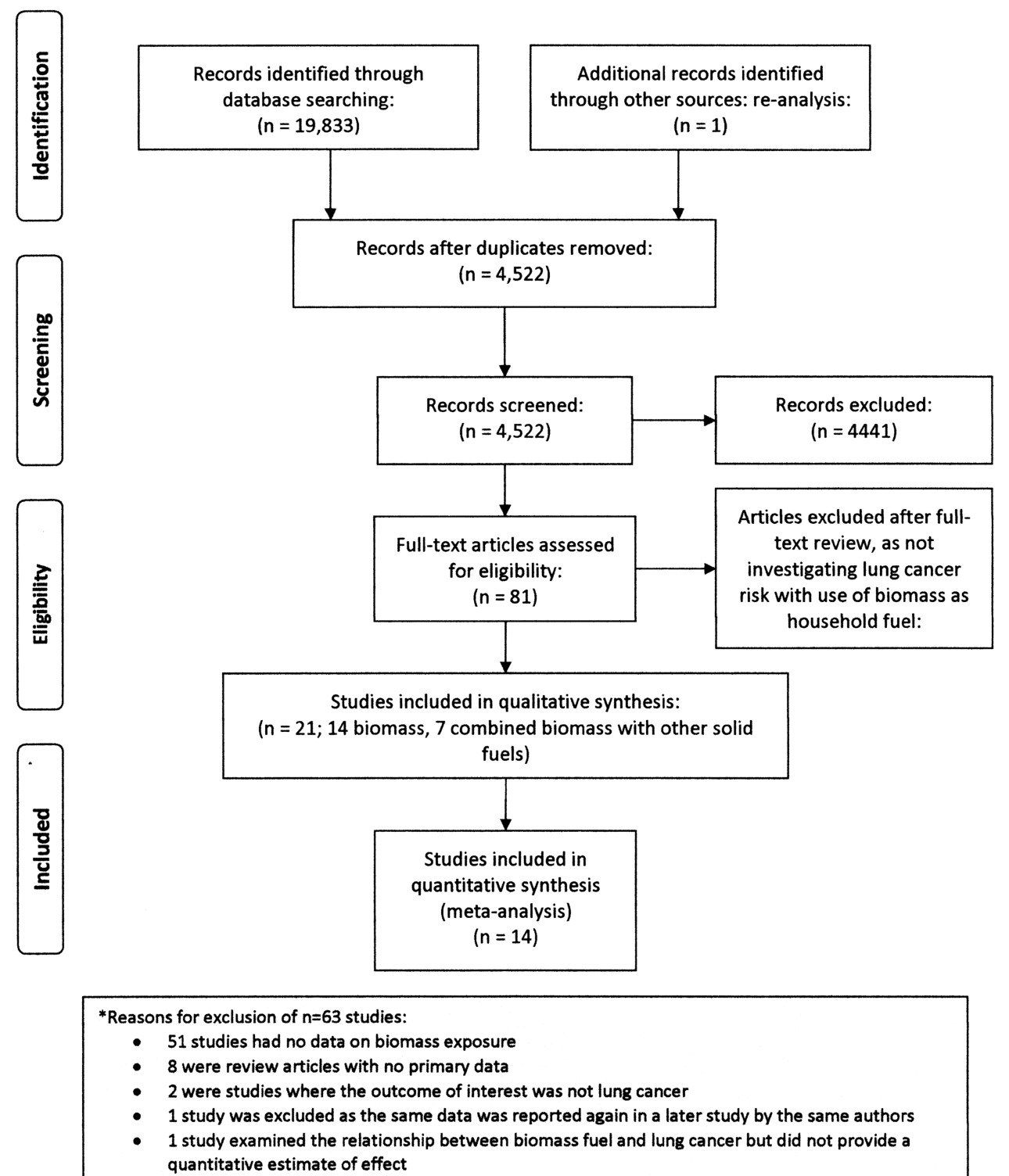

Figure 1 Flow diagram.

Ten studies used hospital controls, two population controls and two used both. One study included a number of conditions known or suspected to be associated with exposure to biomass smoke, including TB, interstitial lung disease, asthma and miscellaneous pulmonary conditions. ${ }^{7}$

All studies used exposure to biomass fuel as a proxy for HAP, and none carried out air quality or exposure measurement. All but one included wood as a cooking fuel in the definition. Two studies, ${ }^{6} 20$ combined wood with grass or straw in the biomass exposure category, while a further two defined biomass fuel as use of wood or charcoal. ${ }^{4}{ }^{19}$ One study used the term biomass without further description of fuels used. ${ }^{17}$ A major concern was that eight of the studies did not specify the type of cooking fuel used in the unexposed group (table 2). Several used ever versus never used wood for cooking, so that it was unclear whether wood was always being compared with clean fuel, as opposed to another solid fuel such as coal. These eight studies were judged to be weak in terms of exposure assessment quality. Lung cancer has a long latent period, so historical and lifetime exposure patterns are important.
Most studies used pathological confirmation for lung cancer diagnosis. Two studies relied on clinical diagnosis, one for all cases ${ }^{20}$ the other with $32 \%$ having pathological confirmation, ${ }^{16}$ and were assessed as weak in this regard. The majority did not differentiate between histological types of lung cancer; one study restricted outcome to adenocarcinoma of the lung, ${ }^{7}$ another provided separate estimates for adenocarcinoma and small cell lung cancer. ${ }^{4}$

Most studies made adjustments for potential confounders such as age, sex and active smoking. However, two studies made no adjustment, ${ }^{16}{ }^{20}$ and were assessed as weak on this quality criterion. Some also adjusted for other potential confounders, such as socio-economic status and environmental tobacco smoke (ETS), and were quality assessed as strong. All other studies were assessed as moderate.

\section{Meta-analysis}

The summary OR for all persons for cooking or heating with biomass was 1.17 (95\% CI 1.01 to 1.37), figure 2, using random effects due to heterogeneity $\left(\mathrm{I}^{2}=43 \%, \mathrm{p}=0.02\right)$. The funnel plot showed no clear evidence of publication bias overall, 
Table 2 Summary of 14 case-control studies included in the systematic review; Lissowska et al ${ }^{5}$ was included in the pooled analysis by Hosgood et al ${ }^{14}$

\begin{tabular}{|c|c|c|c|c|c|c|}
\hline Author and study location & $\begin{array}{l}\text { Study design (all case-control); numbers of } \\
\text { cases and controls; outcome assessment }\end{array}$ & $\begin{array}{l}\text { Cooking fuel type(s); } \\
\text { assessment of duration } \\
\text { of use }\end{array}$ & $\begin{array}{l}\text { Reference } \\
\text { category clearly } \\
\text { using clean } \\
\text { fuel(s) }\end{array}$ & $\begin{array}{l}\text { Adequacy of } \\
\text { adjustment }\end{array}$ & $\begin{array}{l}\text { Non-smoker } \\
\text { analysis* }\end{array}$ & $\begin{array}{l}\text { Results: adjusted } \\
\text { OR }(95 \% \mathrm{CI})\end{array}$ \\
\hline $\begin{array}{l}\text { Behera, } \\
\text { India }^{17}\end{array}$ & $\begin{array}{l}\text { Hospital-based } \\
\text { cases: } 67 \text { (F); } \\
\text { pathologically confirmed controls: } 46 \text { (F) }\end{array}$ & $\begin{array}{l}\text { Biomass for cooking; } \\
\text { duration: current fuel use }\end{array}$ & YEs: use of LPG & Moderate & Not reported & $\begin{array}{l}\text { Women: use of biomass for cooking: } \\
\mathrm{OR}=3.59 \text { (1.07 to } 11.97)\end{array}$ \\
\hline Gupta, India $^{15}$ & $\begin{array}{l}\text { Hospital-based } \\
\text { cases: } 235 \text { (M), } 30 \text { (F); pathologically confirmed } \\
\text { controls: } 525 \text { ( } 2 \text { per case) }\end{array}$ & $\begin{array}{l}\text { Wood for cooking and for } \\
\text { heating; } \\
\text { duration: }<45 \text { and }>45 \text { years } \\
\text { of use }\end{array}$ & $\begin{array}{l}\text { No: never used } \\
\text { wood }\end{array}$ & Moderate & Not reported & $\begin{array}{l}\text { Use of wood for cooking: } \\
\text { Men: } 1-45 \text { years: } \mathrm{OR}=0.94 \text { (0.58 to } 1.54) \\
\text { >45 years: } \mathrm{OR}=0.87(0.58 \text { to } 1.30) \\
\text { Women: } 1-45 \text { years: } \mathrm{OR}=0.74(0.20 \text { to } 2.65) \\
>45 \text { years: } \mathrm{OR}=1.11(0.34 \text { to } 3.60) \\
\text { Use of wood for heating: } \\
\text { Men: } 1-45 \text { years: } \mathrm{OR}=2.62(0.47 \text { to } 14.5) \\
\text { Women: } 1-45 \text { years: } \mathrm{OR}=2.78(0.97 \text { to } 7.98)\end{array}$ \\
\hline Sapkota, India ${ }^{11}$ & $\begin{array}{l}\text { Hospital-based } \\
\text { cases: } 793(88 \% \mathrm{M}) ; 80 \% \text { cases pathologically } \\
\text { confirmed } \\
\text { controls: } 718\end{array}$ & $\begin{array}{l}\text { Wood for cooking; } \\
\text { duration: always used wood }\end{array}$ & $\begin{array}{l}\text { Yes: always used } \\
\text { modern cooking } \\
\text { fuelt }\end{array}$ & Moderate & $\begin{array}{l}\text { Only for all solid } \\
\text { fuels (biomass and } \\
\text { other solid fuels) }\end{array}$ & $\begin{array}{l}\text { Use of wood for cooking: } \\
\text { Men: } \mathrm{OR}=1.30 \text { ( } 0.90 \text { to } 1.87) \\
\text { Women: } \mathrm{OR}=1.01 \text { ( } 0.42 \text { to } 2.41) \\
\text { Men and women non-smokers: } \mathrm{OR}=0.75 \text { ( } 0.45 \text { to } 1.24)\end{array}$ \\
\hline Gao, China ${ }^{18}$ & $\begin{array}{l}\text { Population-based } \\
\text { cases: } 672 \text { (F) } 80 \% \text {; pathologically confirmed } \\
\text { controls: } 735\end{array}$ & $\begin{array}{l}\text { Wood for cooking; } \\
\text { duration: current wood use }\end{array}$ & $\begin{array}{l}\text { No: not currently } \\
\text { using wood }\end{array}$ & Moderate & Not reported & $\begin{array}{l}\text { Women: } \\
\text { Use of wood for cooking: } \\
\text { OR=1.0 (0.6 to } 1.8)\end{array}$ \\
\hline Liu China ${ }^{16}$ & $\begin{array}{l}\text { Hospital-based } \\
\text { cases: } 224(\mathrm{M}) \text { and } 92(\mathrm{~F}) ; 32 \% \text { pathologically } \\
\text { confirmed } \\
\text { controls: } 224(\mathrm{M}) \text { and } 92 \text { (F) }\end{array}$ & $\begin{array}{l}\text { Wood for cooking; } \\
\text { duration: current wood use }\end{array}$ & $\begin{array}{l}\text { No: not currently } \\
\text { using wood }\end{array}$ & Weak & Not reported & $\begin{array}{l}\text { Use of wood for cooking: } \\
\text { Men: estimated (unadjusted) } \mathrm{OR}=1.39 \text { ( } 0.44 \text { to } 4.42 \text { ) } \\
\text { Women: estimated (unadjusted) } \mathrm{OR}=0.84 \text { (0.14 to } 5.0)\end{array}$ \\
\hline Ko, Taiwan ${ }^{19}$ & $\begin{array}{l}\text { Hospital-based } \\
\text { cases: } 105 \text { (F); pathologically confirmed } \\
\text { controls: } 105 \text { (F) }\end{array}$ & $\begin{array}{l}\text { Wood or charcoal for } \\
\text { cooking; duration: cooking } \\
\text { before } 20 \text { years of age, } 20- \\
40 \text { and after } 40\end{array}$ & $\begin{array}{l}\text { Yes: no cooking/ } \\
\text { gas }\end{array}$ & Moderate & $\begin{array}{l}\text { Cases are } \\
\text { non-smoking women }\end{array}$ & $\begin{array}{l}\text { Women: use of wood/charcoal for cooking: } \\
\text { OR=2.7 (0.9 to } 8.9)\end{array}$ \\
\hline Koo, Hong Kong ${ }^{20}$ & $\begin{array}{l}\text { Population-based (poorly described) } \\
\text { cases: } 200 \text { (F); no information on histology } \\
\text { controls: } 200 \text { (F) }\end{array}$ & $\begin{array}{l}\text { Wood or grass for cooking; } \\
\text { duration: ever used wood/ } \\
\text { grass }\end{array}$ & $\begin{array}{l}\text { No: never used } \\
\text { wood/grass }\end{array}$ & Weak & Not reported & $\begin{array}{l}\text { Women: use of biomass for cooking: } \mathrm{OR}=0.74(95 \% \mathrm{Cl} \\
\text { not reported), } \mathrm{p}=0.50\end{array}$ \\
\hline Lee, Taiwan ${ }^{4}$ & $\begin{array}{l}\text { Hospital-based } \\
\text { cases: } 236(\mathrm{M}) \text { and } 291 \text { (F); pathologically } \\
\text { confirmed } \\
\text { controls: } 805 \text { (M and F) }\end{array}$ & $\begin{array}{l}\text { Wood or charcoal for } \\
\text { cooking; duration: asked } \\
\text { about habitual cooking } \\
\text { practice age } 20-40 \text { years }\end{array}$ & $\begin{array}{l}\text { YEs: no cooking } \\
\text { or gas }\end{array}$ & Strong & Not reported & $\begin{array}{l}\text { Women: use of wood/charcoal for small-cell carcinoma: } \\
\mathrm{OR}=3.5(0.9 \text { to12.9); } \\
\text { use of wood/charcoal for adeno-carcinoma: } \mathrm{OR}=3.3 \\
\text { (1.4 to } 8.0)\end{array}$ \\
\hline Sobue, Japan ${ }^{6}$ & $\begin{array}{l}\text { Hospital-based } \\
\text { cases: } 144 \text { (F); pathologically confirmed } \\
\text { controls: } 731 \text { (F) }\end{array}$ & $\begin{array}{l}\text { Wood or grass for cooking; } \\
\text { duration: asked about fuel } \\
\text { use at both } 15 \text { and } 30 \text { years } \\
\text { of age }\end{array}$ & $\begin{array}{l}\text { No: not wood or } \\
\text { grass }\end{array}$ & Moderate & $\begin{array}{l}\text { Cases are } \\
\text { non-smoking women }\end{array}$ & $\begin{array}{l}\text { Women: use of biomass for cooking: } \\
\mathrm{OR}=1.77 \text { (1.08 to } 2.91)\end{array}$ \\
\hline Malats, 6 European; Brazil| ${ }^{22}$ & $\begin{array}{l}\text { Hospital-based } \\
\text { cases: } 17(\mathrm{M}) \text { and } 105(\mathrm{~F}) \text {; pathologically } \\
\text { confirmed } \\
\text { controls: } 34(\mathrm{M}) \text { and } 87 \text { (F) }\end{array}$ & $\begin{array}{l}\text { Wood for cooking or heating; } \\
\text { duration: more than } 20 \text { years } \\
\text { use }\end{array}$ & No: not stated & Strong & $\begin{array}{l}\text { Cases are } \\
\text { non-smoking (M/F } \\
\text { combined) }\end{array}$ & $\begin{array}{l}\text { Men and women: } \\
\text { use of wood for heating or cooking: } \\
\mathrm{OR}=2.50(1.00 \text { to } 6.25)\end{array}$ \\
\hline $\begin{array}{l}\text { Hernandez-Garduno, } \\
\text { Mexico }^{7}\end{array}$ & $\begin{array}{l}\text { Hospital-based } \\
\text { cases: } 113 \text { (F) pathologically confirmed } \\
\text { controlsł: } 273 \text { (F) }\end{array}$ & $\begin{array}{l}\text { Wood for cooking; } \\
\text { duration: } 1-20,21-50 \text { and } \\
>50 \text { years of use }\end{array}$ & $\begin{array}{l}\text { No: never used } \\
\text { wood }\end{array}$ & Strong & $\begin{array}{l}\text { Cases are } \\
\text { non-smoking women }\end{array}$ & $\begin{array}{l}\text { Women: use of wood for cooking: } 1-20 \text { years: } \mathrm{OR}=0.6 \\
\text { (0.3 to } 1.2) ; 21-50 \text { years: } \mathrm{OR}=0.6(0.3 \text { to } 1.3) ; \\
>50 \text { years: } \mathrm{OR}=1.9(1.1 \text { to } 3.5)\end{array}$ \\
\hline
\end{tabular}




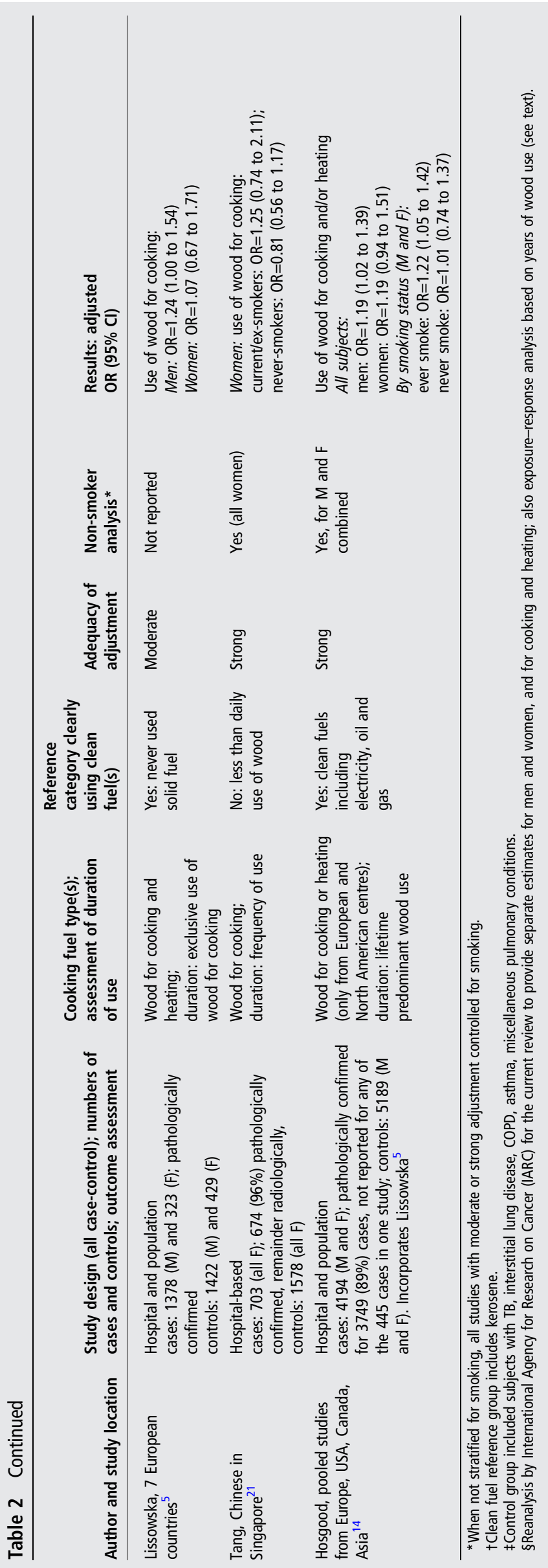

or by sex (see online supplementary figure S1) and there was no statistically significant evidence of asymmetry overall (Begg's test $p=0.398$; Egger's test $p=0.48$ ), for women (Begg's test $\mathrm{p}=0.59$; Egger's test $\mathrm{p}=0.46$ ); or for men (Begg's test $\mathrm{p}=0.46$; Egger's test $\mathrm{p}=0.59$ ).

Men

The four estimates for men had a pooled OR of 1.15 (95\% CI 1.01 to 1.31$)$, using fixed effect meta-analysis $\left(\mathrm{I}^{2}=0 \%\right)$, figure 2 . Given the small number of studies, sensitivity analysis was limited to excluding one study with weak adjustment and without a clean reference group, ${ }^{16}$ and another not specifying a clean reference group; ${ }^{15}$ this yielded an OR of 1.21 (95\% CI 1.05 to 1.39 ) and $\mathrm{I}^{2}=0 \%$. One of the remaining studies included kerosene in the comparison fuel group. ${ }^{11}$ Exclusion of this study left one report (combining four North American and European studies) with an OR of 1.19 (95\% CI 1.02 to 1.39$).{ }^{14}$

\section{Women}

Twelve studies provided estimates for women, with a summary OR of 1.20 (95\% CI 0.95 to 1.52 ) (figure 2) and significant heterogeneity $\left(\mathrm{I}^{2}=51 \%, \mathrm{p}=0.008\right)$. Only four reported significant ORs, which lay in the range of $1.8-3.6 .^{46717}$ Sensitivity analysis was conducted to investigate the heterogeneity, presented in table 3 and discussed further in the online supplementary information. For the majority of sub-analyses heterogeneity remained, but considerably larger and significant effect estimates were found. Restriction to studies reporting a clean fuel reference group ( $n=5$ reports, combining eight studies, all with strong or moderate adjustment) increased the effect to 1.95 (95\% CI 1.16 to 3.27$)$.

\section{Cooking}

Twelve studies provided estimates for cooking, the exposure measure used for the GBD-2010 study. These findings, including sensitivity analysis and results for heating with biomass, are discussed further in the online supplementary information. In summary, the OR for all subjects cooking with biomass was 1.15 (95\% CI 0.97 to $1.37, \mathrm{p}=0.01$ ), with similar but nonsignificant results for men and women. Restriction to studies with at least moderate adjustment and a clean fuel reference group resulted in an OR of 1.95 (95\% CI 1.14 to 3.34), $\mathrm{p}=0.02$ for women (five studies) and of 1.26 (95\% CI 1.04 to 1.52 ), $\mathrm{p}=0.02$ for men (two studies).

\section{Exposure-response evidence}

Only five studies included information on exposure duration, which can be used as a proxy for lifetime dose. Two examined biomass use during different time periods in the subjects' lives, ${ }^{6}{ }^{19}$ while three examined the duration of use. ${ }^{5711}$ These studies are discussed further in the online supplementary information, but overall provided little evidence of consistent or reliable exposure-response relationships. Stronger evidence comes from re-analysis of data from the European case-control study, ${ }^{5}$ which included data on duration of exposure to biomass fuel in four categories (never solid fuel; $0-25 \%$ lifetime use wood; $25-50 \%$ lifetime use wood; and $>50 \%$ lifetime use wood). There was a statistically significant trend for men $(\mathrm{p}<0.01)$ : OR 1.06 (<25\% lifetime); OR 1.13 (25-50\% lifetime); and OR 1.37 (95\% CI 1.03 to 1.81 ), but not for women. The finding for women of higher ORs in the developing country studies (table 3) when restricted to those with at least moderate adjustment and a clean fuel reference group is consistent with the higher exposures observed in developing country homes. ${ }^{23}$ 


\begin{tabular}{|c|c|c|c|c|c|c|c|c|}
\hline Study or Subgroup & log[Odds Ratio] & $\mathrm{SE}$ & Weight & $\begin{array}{c}\text { Odds Ratio } \\
\text { IV, Random, } 95 \% \mathrm{Cl}\end{array}$ & & $\begin{array}{r}\text { Odds } \\
\text { V, Rando }\end{array}$ & $\begin{array}{l}\text { s Ratio } \\
\text { om, } 95 \% \mathrm{Cl}\end{array}$ & \\
\hline \multicolumn{9}{|l|}{ 1.1.1 Men } \\
\hline Gupta 2001(a) & -0.13926 & 0.20589067 & $7.1 \%$ & $0.87[0.58,1.30]$ & & & 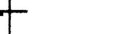 & \\
\hline Gupta 2001(b) & -0.0619 & 0.2491 & $5.8 \%$ & $0.94[0.58,1.53]$ & & & - & \\
\hline Hosgood 2010 & 0.174 & 0.0786 & $12.1 \%$ & $1.19[1.02,1.39]$ & & & - & \\
\hline Liu 1993 & 0.32930375 & 0.59 & $1.6 \%$ & $1.39[0.44,4.42]$ & & & & \\
\hline $\begin{array}{l}\text { Sapkota } 2008 \\
\text { Subtotal }(95 \% \mathrm{Cl})\end{array}$ & 0.2623643 & 0.186556 & $\begin{array}{r}7.8 \% \\
34.4 \%\end{array}$ & $\begin{array}{r}1.30[0.90,1.87] \\
1.15[1.01,1.31]\end{array}$ & & & 5 & \\
\hline \multicolumn{9}{|c|}{$\begin{array}{l}\text { Heterogeneity: } \text { Tau }^{2}=0.00 ; \mathrm{Ch}^{2}=3.22, \mathrm{df}=4(P=0.52) ; \mathrm{I}^{2}=0 \% \\
\text { Test for overall effect: } Z=2.12(P=0.03)\end{array}$} \\
\hline \multicolumn{9}{|l|}{ 1.1.2 Women } \\
\hline Behera 2005 & 1.27926579 & 0.613784 & $1.5 \%$ & $3.59[1.08,11.97]$ & & & & \\
\hline Gao 1987 & 0 & 0.280258 & $5.1 \%$ & $1.00[0.58,1.73]$ & & & & \\
\hline Gupta 2001(a) & 0.10436002 & 0.60197538 & $1.5 \%$ & $1.11[0.34,3.61]$ & & & & \\
\hline Gupta 2001(b) & -0.3011 & 0.6592 & $1.3 \%$ & $0.74[0.20,2.69]$ & & & & \\
\hline Hernandez 2004(a) & -0.51083 & 0.35364652 & $3.7 \%$ & $0.60[0.30,1.20]$ & & & & \\
\hline Hernandez 2004(b) & -0.5108 & 0.3537 & $3.7 \%$ & $0.60[0.30,1.20]$ & & & & \\
\hline Hernandez 2004(c) & 0.6419 & 0.2953 & $4.7 \%$ & $1.90[1.07,3.39]$ & & & & \\
\hline Hosgood 2010 & 0.174 & 0.1203 & $10.4 \%$ & $1.19[0.94,1.51]$ & & & 7 & \\
\hline Ko 1997 & 1.0098 & 0.5978 & $1.6 \%$ & $2.75[0.85,8.86]$ & & & & \\
\hline Koo 1983 & -0.30110509 & 0.34805 & $3.8 \%$ & $0.74[0.37,1.46]$ & & & 一 & \\
\hline Lee 2001(a) & 1.25276297 & 0.67923159 & $1.2 \%$ & $3.50[0.92,13.25]$ & & & & \\
\hline Lee 2001(b) & 1.1939 & 0.4446 & $2.6 \%$ & $3.30[1.38,7.89]$ & & & & \\
\hline Liu 1993 & -0.17435339 & 0.91 & $0.7 \%$ & $0.84[0.14,5.00]$ & & & & \\
\hline Sapkota 2008 & 0.0099503 & 0.444635 & $2.6 \%$ & $1.01[0.42,2.41]$ & & & & \\
\hline Sobue 1990 & 0.57097955 & 0.25285511 & $5.7 \%$ & $1.77[1.08,2.91]$ & & & & \\
\hline Tang 2010(a) & 0.2231 & 0.2675 & $5.4 \%$ & $1.25[0.74,2.11]$ & & & & \\
\hline $\begin{array}{l}\text { Tang } 2010(\mathrm{~b}) \\
\text { Subtotal }(95 \% \mathrm{Cl})\end{array}$ & -0.2107 & 0.1883 & $\begin{array}{r}7.7 \% \\
63.2 \%\end{array}$ & $\begin{array}{l}0.81[0.56,1.17] \\
\mathbf{1 . 2 0}[0.95,1.52]\end{array}$ & & & & \\
\hline \multicolumn{9}{|c|}{$\begin{array}{l}\text { Heterogeneity: } \text { Tau }^{2}=0.10 ; \mathrm{Chi}^{2}=32.58, \mathrm{df}=16(P=0.008) ; I^{2}=51 \% \\
\text { Test for overall effect: } Z=1.54(P=0.12)\end{array}$} \\
\hline \multicolumn{9}{|l|}{ 1.1.3 Men and Women } \\
\hline $\begin{array}{l}\text { Malats } 2000 \\
\text { Subtotal }(95 \% \mathrm{Cl})\end{array}$ & 0.9163 & 0.4675 & $\begin{array}{l}2.4 \% \\
2.4 \%\end{array}$ & $\begin{array}{l}2.50[1.00,6.25] \\
2.50[1.00,6.25]\end{array}$ & & & & \\
\hline \multicolumn{9}{|c|}{$\begin{array}{l}\text { Heterogeneity: Not applicable } \\
\text { Test for overall effect: } Z=1.96(P=0.05)\end{array}$} \\
\hline Total $(95 \% \mathrm{Cl})$ & & & $100.0 \%$ & $1.17[1.01,1.37]$ & & & & \\
\hline $\begin{array}{l}\text { Heterogeneity: } \mathrm{Tau}^{2}= \\
\text { Test for overall effect } \\
\text { Test for subgroup diff }\end{array}$ & $\begin{array}{l}.05 ; \mathrm{Chi}^{2}=38.51, \\
\mathrm{Z}=2.03(\mathrm{P}=0.04) \\
\text { rences: } \mathrm{Chi}^{2}=2.76\end{array}$ & $d f=22(P$ & $0.02) ; 1^{2}$ & & $\begin{array}{ll}1 & 1 \\
0.1 & 0.2 \\
& \text { Lo }\end{array}$ & $\begin{array}{l}0.5 \\
\text { wer risk }\end{array}$ & 12 & 10 \\
\hline
\end{tabular}

Figure 2 Forest plot of 13 studies (23 estimates) reporting risk of lung cancer with use of biomass fuel in the household, stratified by sex. Notes on studies with more than one estimate (see table 2 for details):

\begin{tabular}{|c|c|}
\hline $\begin{array}{l}\text { Gupta et al 2001(a) } \\
\text { Gupta et al 2001(b) }\end{array}$ & $\begin{array}{l}\text { Use of wood for cooking }>45 \text { years } \\
\text { Use of wood for cooking } 1-45 \text { years }\end{array}$ \\
\hline $\begin{array}{l}\text { Hernandez et al 2004(a) }{ }^{7} \\
\text { Hernandez et al 2004(b) } \\
\text { Hernandez et al 2004(c) }\end{array}$ & $\begin{array}{l}\text { Use of wood for cooking } 1-20 \text { years } \\
\text { Use of wood for cooking } 21-50 \text { years } \\
\text { Use of wood for cooking }>50 \text { years }\end{array}$ \\
\hline $\begin{array}{l}\text { Lee et al } 2001(a)^{4} \\
\text { Lee et al } 2001(b)^{4}\end{array}$ & $\begin{array}{l}\text { Use of wood or charcoal for risk of small cell carcinoma } \\
\text { Use of wood or charcoal for risk of adenocarcinoma }\end{array}$ \\
\hline $\begin{array}{l}\text { Tang et al 2010(a) } \\
\text { Tang et al } 2010(b)^{21}\end{array}$ & $\begin{array}{l}\text { Use of wood for cooking in current/ex-smokers } \\
\text { Use of wood for cooking in never smokers }\end{array}$ \\
\hline
\end{tabular}

\section{DISCUSSION}

This systematic review updates the epidemiologic evidence linking HAP from household biomass fuel use and risk of lung cancer as reported by IARC, ${ }^{3}$ and meta-analysis provides sexspecific risk estimates for heating and/or cooking with biomass, as well as for cooking only. It provided the risk estimates used for cooking with biomass in the GBD-2010 study. ${ }^{8}$ There were insufficient studies to derive a separate effect estimate for household heating with biomass fuel.

In 13 case-control studies, the overall OR for biomass use for heating and/or cooking was 1.17 (95\% CI 1.01 to 1.37 ). For cooking, 12 studies provided an OR of 1.15 (95\% CI 0.97 to 1.37), with similar effect sizes stratified by sex. Overall, these studies were subject to methodological limitations, the most important being that more than half did not explicitly compare biomass with a clean fuel. Analysis restricted to studies making a clean fuel comparison, and carrying out at least moderately complete adjustment for confounding, found larger risk estimates among both men and women of 1.21 (95\% CI 1.05 to 1.39 ), $\mathrm{p}=0.01$ and 1.95 (95\% CI 1.16 to 3.27), $p=0.01$, respectively. The estimate was further increased among women with exclusion of one study with kerosene in the clean fuel group to 2.33 (95\% CI 1.23 to 4.42). $\mathrm{p}=0.01$, consistent with the tentative evidence of cancer risk from the use of this fuel, especially in wick stoves that have been in common use in India. ${ }^{24}$ Similar sub-analysis of the cooking-only estimates provided comparable results, although higher for women. 
Table 3 Sensitivity analyses of risk of lung cancer for cooking and/or heating with biomass fuels for women

\begin{tabular}{|c|c|c|c|c|c|c|c|}
\hline \multirow[b]{2}{*}{ Group } & \multicolumn{2}{|c|}{ Sensitivity analysis } & \multirow{2}{*}{$\begin{array}{l}\text { Number } \\
\text { of studies }\end{array}$} & \multirow{2}{*}{$\begin{array}{l}\text { Heterogeneity } \\
\left(\mathrm{I}^{2} ; \mathrm{p} \text {-value) }\right.\end{array}$} & \multirow{2}{*}{$\begin{array}{l}\text { OR }(95 \% \mathrm{Cl}) \\
\mathrm{FE}=\text { fixed effects }\end{array}$} & \multirow[b]{2}{*}{ p Value } & \multirow[b]{2}{*}{ References } \\
\hline & \# & Sub-group & & & & & \\
\hline \multirow[t]{2}{*}{ All } & 1 & All studies & 12 & $\begin{array}{l}51 \% \\
(p=0.008)\end{array}$ & $1.20(0.95$ to 1.52$)$ & 0.12 & $4671114-22$ \\
\hline & 2 & Clean fuel comparison & 5 & $56 \%(p=0.04)$ & 1.95 (1.16 to 3.27$)$ & 0.01 & 411141719 \\
\hline \multirow[t]{3}{*}{ Design } & 3 & Hospital & 9 & $\begin{array}{l}57 \% \\
(p=0.005)\end{array}$ & $1.31(0.95$ to 1.80$)$ & 0.10 & 46711 15-171921 \\
\hline & 4 & Population & 2 & $0 \%$ & $0.89(0.58$ to 1.37$)$ (FE) & 0.59 & 1820 \\
\hline & 5 & Mixed $^{*}$ & 1 & $\mathrm{~N} / \mathrm{A}$ & $1.19(0.94$ to 1.51$)$ & 0.15 & 14 \\
\hline \multirow{3}{*}{$\begin{array}{l}\text { Strong or moderate } \\
\text { adjustment }\end{array}$} & 6 & All & 11 & $51 \%(p=0.01)$ & $1.23(0.98$ to 1.55$)$ & 0.07 & 4-7 $1114 \quad 15 \quad 17-1921$ \\
\hline & 7 & Clean fuel comparisont & 5 & $56 \%(p=0.04)$ & 1.95 (1.16 to 3.27$)$ & 0.01 & 411141719 \\
\hline & 8 & $\begin{array}{l}\text { Clean fuel comparison, } \\
\text { excluding } \\
\text { kerosene in comparison group }\end{array}$ & 4 & $64 \%(p=0.03)$ & $2.33(1.23$ to 4.42$)$ & 0.01 & 4141719 \\
\hline \multirow[t]{3}{*}{ Asia and Mexico } & 9 & All & 11 & $\begin{array}{l}53 \% \\
(p=0.006)\end{array}$ & $1.22(0.93$ to 1.61$)$ & 0.16 & $4671115-21$ \\
\hline & 10 & Clean fuel comparison & 4 & $21 \%(p=0.28)$ & $2.33(1.46$ to 3.72$)(\mathrm{FE})$ & 0.0004 & 4111719 \\
\hline & 11 & $\begin{array}{l}\text { Clean fuel comparison, } \\
\text { excluding } \\
\text { kerosene in comparison group }\end{array}$ & 3 & $0 \%$ & $3.26(1.88$ to 5.65$)$ (FE) & $<0.0001$ & 41719 \\
\hline $\begin{array}{l}\text { Europe, North } \\
\text { America, Brazil }\end{array}$ & 12 & All (all clean fuel)* & 1 & $\mathrm{~N} / \mathrm{A}$ & $1.19(0.94$ to 1.51$)$ & 0.15 & 14 \\
\hline \multirow[t]{2}{*}{ Non-smokers only } & 13 & All & 4 & $\begin{array}{l}66 \% \\
(p=0.007)\end{array}$ & $1.14(0.78$ to 1.67$)$ & 0.50 & 671921 \\
\hline & 14 & Clean fuel comparison & 1 & N/A & 2.75 (0.85 to 8.86$)$ & 0.09 & 19 \\
\hline
\end{tabular}

Further sensitivity analysis carried out among studies with estimates for women (too few available for men) did not reveal other important effects relating to study features, with the exception of geographical location. Among studies with clean fuel comparisons and at least moderate adjustment, those from lower-income settings (Asia and Mexico) showed substantially higher risk than those from more developed countries, consistent with higher exposure levels in the former. ${ }^{23}$

These results provide compelling evidence of an important association between biomass fuel use and lung cancer in both men and women. The Hill viewpoints ${ }^{25}$ provide a useful framework for assessing causal evidence, and are still seen as valid in most regards. ${ }^{26}$ An assessment of these is summarised in table 4.

Although the strength of the summary association is quite weak for all studies combined, when restricted to women (the group with highest exposures), at least moderate adjustment and clean fuel reference, significant ORs in the range from 1.6 to more than 2 were found, indicating that the true effect may be stronger than that seen in the effect estimates for all studies. Studies with estimates for men were consistent, with no heterogeneity. By contrast, there was a general lack of consistency between the studies of women, which may be explained by differences in exposure levels (eg, developed vs developing countries) and aspects of methodology (eg, fuel used in comparison group). Thus, the four higher quality studies from Asia and Mexico had much reduced heterogeneity, and the $\mathrm{I}^{2}$ was zero with further exclusion of the study using kerosene in the comparison group, table 3.

Regarding temporality, there is good reason to expect that cases with exposure to biomass would have experienced this many years prior to the development of cancer, and it is more likely that cases reporting clean fuel use would have had prior exposure to biomass, at least in developing countries, resulting in some exposure misclassification.

Although an exposure-response relationship was found for men in re-analysis of the Lissowska dataset, little convincing evidence of this was reported from other studies: this may reflect in part the generally poor assessment of exposure, and confusion about use of clean versus solid fuels at various times in subjects' lives. The finding that risks were higher among women in the developing compared with developed country settings is consistent with there being higher exposure in the former.

Data on mechanisms of carcinogenicity were reviewed in the IARC Monograph; ${ }^{3}$ there is good mechanistic evidence of the carcinogenicity of biomass smoke, which includes several known carcinogens including polyaromatic hydrocarbons. ${ }^{28-30} \mathrm{~A}$ recent study of young (range 27-42 years), non-smoking women from rural India has shown higher levels of metaplastic and dysplastic changes in airway epithelial cells in those habitually cooking with biomass in comparison with age-matched women cooking with LPG. ${ }^{31}$ There was also evidence of greater upregulation of phosphorylated Akt (protein kinase B), and of higher levels of oxidative stress, both of which are implicated in tumourigenesis. These differences between biomass and LPG cooking groups were associated with substantially higher levels of kitchen $\mathrm{PM}_{10}$, $\mathrm{PM}_{2.5}$, Benzo (a) pyrene and $\mathrm{NO}_{2}$, and of a benzene metabolite measured in the women's urine.

Experimental studies on cancer in animals were also reviewed in the IARC Monograph. ${ }^{3}$ No experimental or other intervention-based evidence in human populations is available to date. The reported risks associated with analogous exposures, notably the effects of active smoking, emissions from coal used for heating and cooking fuel, ${ }^{27}$ ETS ${ }^{32}$ and outdoor air pollution, ${ }^{33}$ on lung cancer are now well established. 
Table 4 Evaluation of Hill viewpoints for causal inference about the association between exposure to household biomass fuel use and lung cancer

\section{Viewpoint}

1 Strength of association

2 Consistency across populations, study designs

3 Specificity

4 Temporality (exposure precedes outcome)

5 Biological gradient (dose-response)

6 Biological plausibility

7 Coherence with natural history, animal studies

8 Experiment

9 Analogy

\section{Explanation}

The strength of association for all studies combined is weak, for men and women. When restricted to studies among women (the majority) with at least moderate adjustment and explicit clean fuel reference group, larger ORs are seen, in the range 1.6->2, depending on the sub-analysis criteria. When restricted to studies in developing countries where exposure is expected to be higher, an effect $>2$ is also seen for studies with at least moderate adjustment and a clean fuel reference group.

All studies used a case-control design, although control selection and exposure definitions varied substantially. Findings for studies overall are consistent for men (five estimates; $I^{2}=0$ ), but not for women among whom high levels of statistical heterogeneity are seen overall and for most sub-analyses. Heterogeneity was, however, much reduced with analysis stratified by developed vs developing country settings, particularly with the latter restricted to studies with at least moderate adjustment and a clean fuel reference group.

Biomass smoke exposure is linked to a wide range of outcomes; specificity is a viewpoint that is no longer considered useful. ${ }^{26}$ Although studies were retrospective case-control designs, subjects exposed at the time of data collection would almost certainly have been exposed in the past for many years, and duration of exposure was assessed in some. Bias (towards the null) is also possible in reference groups reporting current use of clean fuel, as at least some of these subjects may well have had prior exposure to biomass fuel during the latent period for the development of lung cancer.

A dose-response relationship was reported only from the re-analysis of European data in the Lissowska et al study ${ }^{5}$ and only statistically significant for men.

Strong evidence is available on biological plausibility. Evidence on mutagenicity and other mechanisms was summarised in the International Agency for Research on Cancer (IARC) monograph review, and noted (1) the presence of polycyclic aromatic hydrocarbons and other established carcinogenic compounds at levels in wood smoke that are known to be carcinogenic, (2) evidence of mutagenicity of woodsmoke, and (3) multiple studies that show cytogenetic damage in humans who are exposed to wood smoke. ${ }^{3}$

Globally, rates of lung cancer incidence and mortality are driven primarily by smoking, and where studied within China for household fuel by the use and type of coal. ${ }^{27}$ This review has found evidence of higher risk in studies from parts of the world expected to have higher exposure to biomass smoke. Evidence from animal studies was summarised by the IARC monograph review, and described as limited for the carcinogenicity of emissions from combustion of wood, but sufficient for the carcinogenicity of wood smoke extracts.

No experimental or intervention-based epidemiologic evidence for biomass and lung cancer is available.

Evidence from other combustion sources, including active and second-hand tobacco smoking, and ambient air pollution, is well established.
A second systematic review of solid fuel use and lung cancer was published by Kurmi et $a l^{34}$ and included seven studies (nine estimates) for biomass. The review included all study designs, biomass use for cooking and/or heating, but only incorporated adjusted estimates. ${ }^{34}$ The pooled OR was somewhat higher than for the current review at 1.50 (1.17 to 1.94$)$, with $\mathrm{I}^{2}=41.2 \%$ $(\mathrm{p}=0.092)$; Eggar's test for publication bias was non-significant. The results for men were 1.78 (0.46 to 6.93) and for women 1.98 (1.44 to 2.71$)$. Sensitivity analysis examining studies that adjusted for smoking found an OR of 1.36 (0.99 to 1.86), and an OR of 1.42 (1.04 to 1.94$)$ for those with a higher quality score. In summary, the findings for studies with better adjustment and quality are consistent with similar restricted sensitivity analysis in the current review.

\section{CONCLUSION}

Taken as a whole, this review provides stronger evidence than was previously available on the association between household use of biomass fuel for cooking and the risk of lung cancer. For women, sub-analysis of higher quality studies with clean fuel reference groups report moderately strong effects, support causal inference (table 4), notwithstanding the limited exposure-response and absence of evidence from intervention-based studies. For men, although there are few studies (five in total, only two with clean fuel comparisons), these are consistent and include one with a significant exposure-response relationship. Higher risk estimates in women than in men, and in studies carried out in developing compared with developed country populations, are also findings consistent with higher average exposures leading to higher risk.
It is therefore concluded that the epidemiologic evidence for risk of lung cancer with exposure to biomass fuel use in the household setting is consistent with the observed associations being causal.

The most relevant estimates of effect for cooking and/or heating with biomass fuels are those derived from the studies with clean fuel reference groups and at least moderate adjustment, namely 1.21 (95\% CI 1.05 to 1.39 ), $\mathrm{p}=0.01$ for men, and 1.95 (95\% CI 1.16 to 3.27 ), $\mathrm{p}=0.01$ for women. It can be expected that future studies will modify these estimates, in particular those employing improved exposure assessment, providing a clearer contrast between lifetime biomass and clean fuel exposure as well exposure-response analysis. Given the continuing, extensive use of biomass as a household fuel throughout the developing world, this evidence adds further to concerns about the resulting disease burden.

\section{Author affiliations}

${ }^{1}$ Department of Public Health and Policy, University of Liverpool, Liverpool, UK ${ }^{2}$ Environmental Health Sciences, School of Public Health, University of California Berkeley, California, USA

${ }^{3}$ Division of Cancer Epidemiology and Genetics, Department of Health and Human Services, National Cancer Institute, National Institutes of Health, Bethesda, Maryland, USA

${ }^{4}$ Division of Epidemiology, Albert Einstein College of Medicine, Bronx, New York, USA

${ }^{5}$ Maryland Institute for Applied Environmental Health, University of Maryland, School of Public Health, College Park, Maryland, USA

${ }^{6}$ International Agency for Research on Cancer, Lyon, France

Acknowledgements This work was undertaken as a part of the Global Burden of Diseases, Injuries, and Risk Factors Study 2010. We wish to acknowledge the contribution of Dr Imran Choudhury in assisting with the search, study selection and analysis.

Contributors NB led the design of the review, assisted with search, extraction, quality assessment and analysis, drafted the text and managed the incorporation of 
all coauthor comments; he is responsible for the overall content of the paper. MD assisted with the design of the review, carried out the search, selection, data extraction and quality assessment, and contributed to the text.

$\mathrm{KS}, \mathrm{DH}, \mathrm{AS}$ and QL assisted with the design of the review, advised on study selection, and contributed to the text. RL carried out the Chinese language search, selection, data extraction and quality assessment, and contributed to the text. KS carried out new analysis of the Lissowska et al dataset, advised on data analysis and interpretation, and contributed to the text.

DP co-led the design of the review, assisted with search, extraction and quality assessment, conducted analysis, and contributed to the text.

Funding A grant from the Bill and Melinda Gates Foundation partially supported the collaboration between some of the authors of this review.

Competing interests None.

Provenance and peer review Not commissioned; internally peer reviewed.

Data sharing statement All data used for this systematic review and meta-analysis are included in the text.

\section{REFERENCES}

1 Bonjour S, Adair-Rohani H, Wolf J, et al. Solid fuel use for household cooking: country and regional estimates for 1980-2010. Environ Health Perspect 2013;121:784-90.

2 Bruce N, Perez-Padilla R, Albalak R. Indoor air pollution in developing countries: a major environmental and public health challenge. Bull World Health Organ 2000;78:1078-92.

3 IARC. Household use of solid fuels and high-temperature frying evaluation of carcinogenic risks to humans. Lyon, France: International Agency for Research on Cancer, 2010.

4 Lee $\mathrm{CH}$, Ko YC, Cheng LS, et al. The heterogeneity in risk factors of lung cancer and the difference of histologic distribution between genders in Taiwan. Cancer Causes Control 2001:12:289-300.

5 Lissowska J, Bardin-Mikolajczak A, Fletcher T, et al. Lung cancer and indoor pollution from heating and cooking with solid fuels: the IARC International Multicenter Case-Control Study in Eastern/Central Europe and the United Kingdom. Am J Epidemiol 2005;162:326-33.

6 Sobue T. Association of indoor air pollution and lifestyle with lung cancer in Osaka, Japan. Int J Epidemiol 1990;19(Suppl 1):S62-6.

7 Hernandez-Garduno E, Brauer M, Perez-Neria J, et al. Wood smoke exposure and lung adenocarcinoma in non-smoking Mexican women. Int J Tuberc Lung Dis 2004;8:377-83.

8 Lim SS, Vos T, Flaxman AD, et al. A comparative risk assessment of burden of disease and injury attributable to 67 risk factors and risk factor clusters in 21 regions, 1990-2010: a systematic analysis for the Global Burden of Disease Study 2010. Lancet 2012;380:2224-60.

9 Moher D, Liberati A, Tetzlaff J, et al. Preferred reporting items for systematic reviews and meta-analyses: the PRISMA statement. PLoS Med 2009;6.

10 Cochrane-IMS. Review Manager (software). Secondary Review Manager (software) 2014. http://ims.cochrane.org/revman

11 Sapkota A, Gajalakshmi V, Jetly DH, et al. Indoor air pollution from solid fuels and risk of hypopharyngeal/laryngeal and lung cancers: a multicentric case-control study from India. Int J Epidemiol 2008;37:321-8.

12 Der Simonian R, Laird N. Meta-analysis in clincial trials. Control Clin Trials 1986;7:177-88.

13 StataCorp. Stata Statistical Software: Release 10. College Station, TX: StataCorp LP, 2007.
14 Hosgood DI, Boffetta P, Greenland S, et al. In-home coal and wood use and lung cancer risk: a pooled analysis of the International Lung Cancer Consortium. Environ Health Perspect 2010;118(12):1743-7.

15 Gupta D, Boffetta P, Gaborieau V, et al. Risk factors of lung cancer in Chandigarh, India. Indian J Med Res 2001;113:142-50.

16 Liu Q, Sasco AJ, Riboli E, et al. Indoor air pollution and lung cancer in Guangzhou, People's Republic of China. Am J Epidemiol 1993;137:145-54.

17 Behera D, Balamugesh T. Indoor air pollution as a risk factor for lung cancer in women. J Assoc Physicians India 2005;53:190-2.

18 Gao YT, Blot WJ, Zheng W. Lung cancer among Chinese women. Int J Cancer 1987;40:5.

19 Ko YC, Lee $\mathrm{CH}$, Chen MJ, et al. Risk factors for primary lung cancer among non-smoking women in Taiwan. Int J Epidemiol 1997;26:24-31.

20 Koo LC, Lee $\mathrm{N}, \mathrm{Ho} \mathrm{JH}$. Do cooking fuels pose a risk for lung cancer? A case-control study of women in Hong Kong. Ecol Dis 1983;2:255-65.

21 Tang L, Lim W-Y, Eng P, et al. Lung cancer in Chinese women: evidence for an interaction between tobacco smoking and exposure to inhalants in the indoor environment. Environ Health Perspect 2010;118:1257-60.

22 Malats N, Camus-Radon A-M, Nyberg F, et al. Lung cancer risk in nonsmokers and GSTM1 and GSTT1 genetic polymorphism. Cancer Epidemiol Biomarkers Prev 2000;9:827-33.

23 Balakrishnan K, Ghosh S, Ganguli B, et al. State and national household concentrations of PM2.5 from solid cookfuel use: results from measurements and modeling in India for estimation of the global burden of disease. Environmental Health 2013;12:77.

24 Lam NL, Smith KR, Gauthier A, et al. Kerosene: a review of household uses and their hazards in low- and middle-income countries. J Toxicol Environ Health B Crit Rev 2012;15(6):396-432.

25 Hill AB. The environment and disease: association or causation? Proc $R$ Soc Med 1965;58:295-300.

26 Howick J, Glasziou P, Aronson JK. The evolution of evidence hierarchies: what can Bradford Hill's 'guidelines for causation' contribute? J $R$ Soc Med 2009;102:184-94.

27 Hosgood HD III, Wei H, Sapkota A, et al. Household coal use and lung cancer: systematic review and meta-analysis of case-control studies, with an emphasis on geographic variation. Int J Epidemiol 2011;40:719-28.

28 Bell DA, Karam H, Kamens RM. Nonaqueous ion-exchange separation technique for use in bioassay-directed fractionation of complex mixtures: application to wood smoke particle extracts. Environ Sci Technol 1990;24:1261-4.

29 Kamens R, Bell D, Dietrich A, et al. Mutagenic transformations of dilute wood smoke systems in the presence of ozone and nitrogen dioxide. Analysis of selected high-pressure liquid chromatography fractions from wood smoke particle extracts. Environ Sci Technol 1985;19:63-9. Environ Mol Mutagen

30 Musthapa MS, Lohani M, Tiwari S, et al. Cytogenetic biomonitoring of Indian women cooking with biofuels: micronucleus and chromosomal aberration tests in peripheral blood lymphocytes. 2004;43:243-9.

31 Roychoudhury S, Mondal NK, Mukherjee S, et al. Activation of protein kinase B (PKB/Akt) and risk of lung cancer among rural women in India who cook with biomass fuel. Toxicol Appl Pharmacol 2012;259:45-53.

32 Zhong L, Goldberg MS, Parent ME, et al. Exposure to environmental tobacco smoke and the risk of lung cancer: a meta-analysis. Lung Cancer 2000;27:3-18.

33 Cohen AJ, Ross Anderson H, Ostro B, et al. The global burden of disease due to outdoor air pollution. J Toxicol Environ Health A 2005;68:1301-7.

34 Kurmi OP, Arya PH, Lam KBH, et al. Lung cancer risk of solid fuel smoke exposure: a systematic review and meta-analysis. Eur Respir J 2012;40: 1228-37. 